\title{
Early Childhood Cognitive Development Through Games Educational Tool
}

\author{
Suprayitno Sutoyo \\ Visual Communication Design \\ School of Design \\ Bina Nusantara University \\ Jakarta, Indonesia \\ praysutoyo@binus.ac.id
}

\begin{abstract}
Games Educational Tool are all things that can be used as a medium to play that have educational value, one of the benefits is that it helps the growth of all aspects of physical and cognitive abilities. This study will explain how the media has a very important role in stimulating the growth of a child's brain. Using descriptive qualitative method to determine the cognitive educational element in the game. The results of this study to prove that media educational games have a major role in the cognitive abilities of children floating.
\end{abstract}

Keywords—educational games, cognitive, early childhood

\section{INTRODUCTION}

Early Childhood Education (Pendidikan Anak Usia Dini $P A U D)$ is the level of education before primary education which is an approach to development that is intended for children from birth up to the age of six years are accomplished by providing stimulation of education to help the growth and development of the physical and spiritual so that children have the readiness to enter further education, which was held in formal, non-formal and informal.

Early childhood education is one form of organization of education that focuses on laying the foundation toward growth and 5 development, namely: the development of moral and religious, psychomotor, intelligence and cognitive, socio-emotional (attitudes and emotions), language and communication, according to the uniqueness and stages of development of the appropriate age group traversed by younger children as stipulated in the Ministerial Regulation No. 58 of 2009.

Early childhood education is indeed a shared responsibility between families, communities and governments. Continuation school as a helper in the family education, because education is first and foremost a child is in the family acquired. The family as the smallest social unit in an educational environment and most major one, in the sense that the family is the most environmentally responsible to educate their children. At the time of between 0-6 years of age, the brain develops very rapidly up to 80 percent. At that age the brain to receive and absorb various kinds of information, do not see the good and the bad. That is the period in which physical, mental and spiritual child will begin to form, are calling as a golden age period.

Games Educational Tool (Alat Permainan Edukasi - APE) is anything that can be used as a medium or media to play that have educational value and can stimulate the growth of a child's brain in the development of the full potential of their ability. According to Rahman [1] tool is a tool of educational games game designed specifically for the benefit of pre-school education in improving aspects of the development of the full potential of the child.

The use of educational games that correspond to the level of child development can help teachers improve their ability. This study focused only on the cognitive abilities of children. Relation to its cognitive abilities, educational games tools so have a very important role in stimulating the growth of a child's brain to be more cognitive. Rahman [1] states that one of the benefits of games or educational tool is to assist the growth of all aspects of physical and cognitive abilities.

Cognitive is a process of thinking, the ability of individuals to connect, assess and consider an incident or event. Ministry of National Education [2] states that, cognitive development aims to develop the ability to think of children's acquisition process of learning, alaternatif can find a variety of problemsolving, helping children to develop logic skills and knowledge of space and time, and have the ability to sort, classifying and preparing the development of the ability to think carefully. In Nasar [3], Piaget stressed that the study is on active learners. Therefore familiarize themselves with approaches that enable teaching students one teacher needs to have two basic skills namely: finding selecting learning resources and learning activities. Furthermore, Jean Piaget described the cognitive abilities of pre-school children are at the stage of pre-operational where children still think in concrete, symbolic and systematic.

To excite or stimulate increased cognitive abilities required media is often called by means of educational games tailored to the age and child development objectives in the learning activities. The role of educational games as a media tool or channel conveying messages to early childhood learning is 
becoming increasingly important, given the development of the child is at the time of concrete thinking, in which children learn to understand a phenomenon or event through real experience directly. Purpose of the game lies in the type of the game itself and is achieved when playing. Children love to play because in them there is an inner urge and the urge to develop themselves. It can be concluded that the tools of educational games has close links with the development of children's cognitive abilities, making it useful for stimulating the growth of a child's brain for optimal cognitive.

The game is also one of the dominant forms of social activity in the early years of children. Because children spend more time to play with friends or play alone. Because it's a game for children is one form of a fun activity that is done solely for the activity itself, not because they want to obtain a result of these activities. This is because the children the process of doing something more interesting than the results would obtainment [4].

At every child, especially small children, playing is learning. The world of children is essentially the world to play, because the game children will learn many things about life everyday. Through the use of game media is good and right, then as a teacher or parent can incorporate educational elements in it.

\section{RESEARCH METHODE}

Qualitative Method-This study used qualitative methods, data collection techniques by observation, interview and documentation. The analysis used is descriptive analysis to describe how the media's role in the development of educational games early childhood cognitive abilities. According Sukmadinata [5] explains that the research is a form of descriptive study aimed to describe the phenomena that exist, whether a natural phenomenon or man-made phenomenon. The phenomenon could be the shape, activity, characteristics, changes, relationships, similarities and differences between the phenomena with each other phenomenon.

Descriptive study by Etna Widodo and Mukhtar [6] most are not intended to test a specific hypothesis, but rather describe what a symptom, variable, or circumstances. However, by no means all descriptive study did not use a hypothesis. The use of hypotheses in a descriptive study is not intended to be tested but how trying to find something that is meant as an alternative to overcome the problem of research through scientific procedures

\section{RESULT AND ANALYSIS}

Field observations also seen that the development of cognitive abilities of children in early childhood school TKIT Ummul Quro, Jl. Parakan Jaya Kec. Kemang, Bogor West Java - Indonesia, very diverse. There are categorized very well developed, evolved as expected, began to grow, and still undeveloped. This happens because of differences in the grasp of reason in each child. Based on previous observations, educational games used media is still in the form of pictures or posters only, and activities that are most often done coloring activity. As a result, children become bored and lazy to carry out learning activities.

Playing in essence is an activity that has the characteristics of an active and fun. Playing also voluntarily performed and generally arise from internal motivation. The game has its benefits, among other things: (a) optimize the physical and mental development of children; (b) meet the emotional needs of the child; (c) develop children's creativity and language skills of children; (d) assist in the socialization of children. Play also serves to develop aspects of the development of motor skills, cognitive, affective, language and social aspects [7].

In order to improve the cognitive abilities of children approach is to use props or media educational games in each learning activity. One problem is still lack of diversity in the type of tool used educational games.

Learning is not confined to acquire knowledge and skills just like writing, reading and arithmetic or another, but also acquire skills and life skills such as attitude of self, habits, hygiene, patriotism, responsibility, confidence and applied skills and values of personality another child. According to Ace Suryadi [8] that the development and quality of children is influenced by many factors, such as heredity and the environment that could include educational interventions.

Ace Suryadi [8] concludes that there is significance between early childhood education with the efforts to unleash the potential of the child at the golden age, because the learning principles of early childhood education is to play while learning according to age, psychological development and specific needs children, and the child closer to the environment

\section{A. Urgency Play for Children}

By playing many aspects of intelligence are honed from the child. Parents consider playing is not a lot of benefits, even tended complaint with the school when they know that school children are only playing, which should be taught about reading, writing and arithmetic. The real fact of the pre-school is a time to play, it is appropriate for learning in kindergarten is done by playing while learning and learn while playing [9].

Play is important for children, because it plays a major part of the growth process of children. Through play, children will learn many things about everyday life. Children will gain experience related to environmental, social, economic, cultural, as well as the surrounding natural environment. So it is very useful to improve language skills, thinking, acting, hanging out, or working. Indirectly play activities children will be more focused to devote attention, feelings, thoughts, through the shape and nature of the game media.

So, generally speaking, the game has the urgency of different cognitive, social and emotional:

(1) The urgency of the cognitive, the game can help the development of the child's thinking. Through play, children explore their environment, learn about the objects around them, and learn to solve his problems. Through the game allows 
children to develop competencies and skills required in a fun way. (2) social urgency, the game can improve and develop the social development of children. Especially in the game of fantasy role play a role, children can learn to understand others while growing up. (3) emotional urgency, the game allows children to solve emotional problems in themselves, learn to cope with anxiety and inner conflict. The game allows children to release excess physical energy and liberate pent-up feelings and the inner pressure can be liberated when they play.

Basically, some of the benefits play for children, and in principle play is to train the senses and other limbs as a preparation for life and the lives of children in the future [10].

Thus, it is clear that the use of media play is one thing that is important in achieving objectives child's learning. Therefore, educators should guide the course of the game is not to hinder the development of children in the cognitive, affective and psychomotor, and provides ample opportunity for play.

\section{B. Selecting Games Educational Tool}

Basically forms and types of educational games is not limited, however, to note that in choosing educational games need to consider several factors as follows: (1) the age factor and the interest of the child, for the purpose of playing really serves to support the growth and development of children's cognitive. (2) safety factor, which is not sharp or no parts that can injure the child and does not contain harmful substances. (3) areas of involvement of a parent or family member in the process of playing, to support the development of the child and so do not turn off their creativity and interests of children. (4) factors of convenience, such as ease of disassembly, can be installed or repaired, making it easier for children to back to playing. (5) factors imagination, media games that are easily shaped and altered very suitable to develop and train the power of imagination.

When children are playing in fact they are learning, children will record everything that happens in the surrounding environment. This is where the importance of parents and educators select and determine the type of game that suits the child's development. Selection and determination of the type of game is identical to the selection of subject matter by the teacher with the development of learners.

Selection of the type of game that suits the child's development is necessary so that the educational messages in every game can be captured and absorbed children with easy and fun. If the selection of games and age of the child does not fit, then that appears is not the benefits, it can even be bad for the formation of character and intelligence. Instead election game that corresponds to the character development of children, it will provide a positive stimulus in the development of intelligence.

The focus and purpose in playful learning is learning that takes precedence. Playing only a means, not an end. The game can be in the form of whatever, either using a tool or not. The main thing is to learn to master or know new things, instead of learning to play a new toy.

Patterns of learning while playing a fun activity and enjoy. Play and learn the condition that has the great potential to be able to shape the character of being a true learner. Learning outcomes of children will increase sharply as more and more games are tested progressively increased level of intelligence.

\section{Implementation Media Educational Games}

Educational games have a significant role in developing the capabilities of the child. A wide range of capabilities that can be developed through educational games is the ability of cognitive, affective and psychomotor.

Play activities can actually be used by parents and educators to guide children to maximize their growth and development early in life. That is because the use of educational games in play activities have a very positive impact for children. Each tool educational games can function multipurpose. Each one a special interest in developing certain aspects of the development of the child, not infrequently one game tool can improve more than one aspect of development.

If we pay attention to children while playing a variety of educational games such as puzzle, peg board, tower bracelet, without realizing these children actually have developed one of the aspects of cognitive ability. This indicates that children have to use the mind to perform activities of preparing or arranging, so that their brains have started trained.

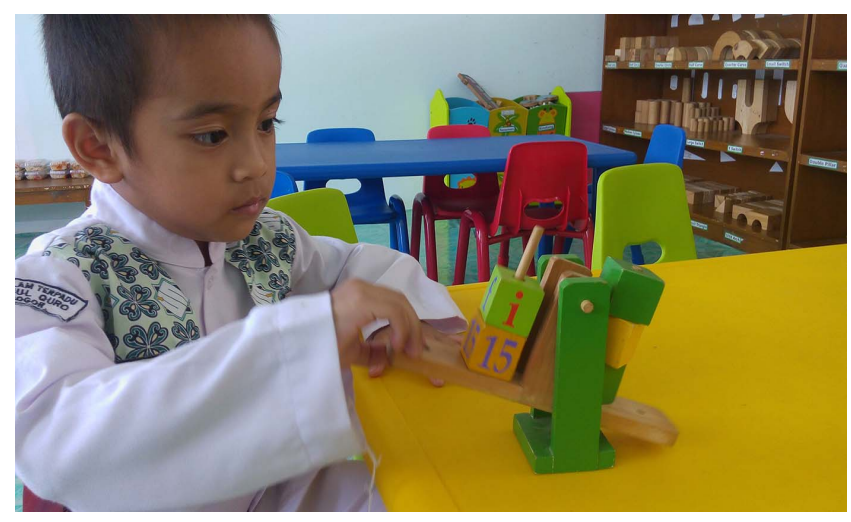

Fig.1, Children are playing with a swing beam in TKIT Ummul Quro Bogor, Source Image: Suprayitno Sutoyo 2016

Here are some benefits of wooden educational toys based on the general concept of a toy or the workings of the most prominent. As Wood Beams/Block : (1) stimulate the logic of a child, (2) Practice patience and the child's independence, (3) Develop creativity and imagination of children, to elaborate right brain functions, (4) Introduce children to the form / elements / colors listed beams, (5) Familiarize children face challenges, (6) Introduce children to the concept of building and causation, (7) Increase confidence of children, because it can foster a sense of 'satisfied' has been able to create something, (8) When playing with another person, such as 
their parents / relatives / friends, toys beams can train children to recognize the concept of cooperation. In addition, children can develop language skills that when children are able to tell what they're doing or sharing toys with others.

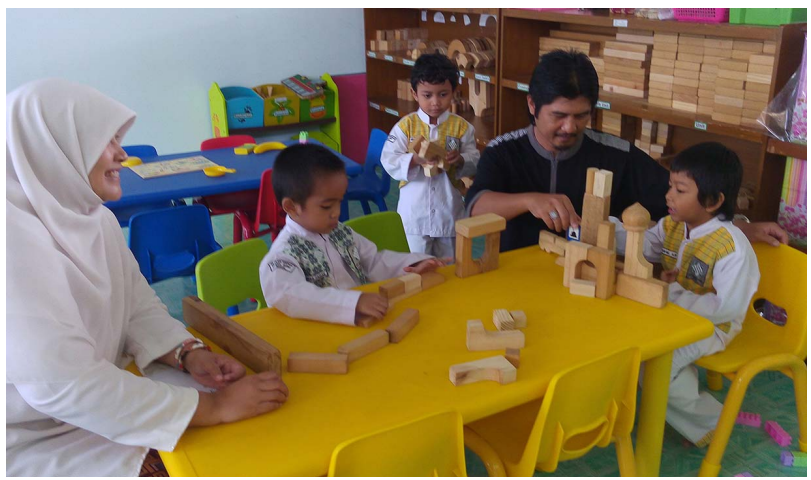

Fig.2, Teacher with children and the author is playing wooden block in TKIT Ummul Quro Bogor, Source Image: Suprayitno Sutoyo 2016

The world of children is the main world playing as a principal activity needs. Therefore, parents who understand this, would not be easy to scold or prohibit their children play. Who knows even a child will become more creative and smarter thanks to his game.

\section{CONCLUTION}

Based on result of data analysis in this study it can be concluded that the tools of educational games has close links with the development of children's cognitive abilities, making it useful for stimulating the growth of a child's brain for optimal cognitive. Tool educational games have a major role in floating the cognitive abilities of children in early childhood school TKIT Ummul Quro - Bogor, West Java, Indonesia. As a medium of learning, educational games proven tool can stimulate cognitive development of children.

Playing is a main activity is quite time consuming, and therefore can not be denied that a child's world is a world of play. Kids and games are two things that are almost inseparable. According to Langeveld [11] game is a flurry of the most essential in the world of children. The game is an activity that contains fun and do on their own will, freely without coercion for the purpose of obtaining pleasure while playing. The game is quite important for the mental development of children. Therefore, it would need for children to be given the opportunity and the means in game activities.
Educational games should be used as the first and main activity in the aspect of a child's life. Because only with the play of children can live happily and be smart.

Almost all kindergarten schools have realized the importance of play for children. The house could actually be a 'school' as well as for their children. That is the time to learn through play at home is much more than in school. It is therefore recommended if children were taught various forms of educational games, that would be at home also provided a game similar to children could repeat the practice game gained in their school.

\section{AUTHOR's BIOGRAPHY}

Suprayitno Sutoyo was born on 30 November 1966 in Wonosobo, Central Java, Indonesia. Completing a Bachelor's degree in Graphic Design at ITB - Institut Teknologi Bandung in 1991, and earned a Master of Graphic Design at the ISI Institut Seni Indonesia, Yogyakarta in 2013. As a lecturer at the New Media School of Design, and Content Specialist Subject to the Course of Surface Packaging Design and Brand Identity, getting the Best Teaching in 2013 and 2015 at Binus University.

\section{REFERENCES}

[1] Rahman, Alat Permainan Edukatif Untuk Program PAUD, Palu: Tadulako University Press, 2010, pp.17-22.

[2] Departemen Pendidikan Nasional, Pembelajaran di Taman Kanak-kanak Didaktik Metodik di TK, Jakarta: Balai Pustaka, 2013, pp.4-5.

[3] Nasar, Merancang pembelajaran aklif dan kontekstual berdasarkan "SISKO", Jakarta: Gerasmdo, 2006, pp.35.

[4] Desmita, Psikologi Perkembangan Anak. Bandung. Remaja Rosdakarya, 2007, pp.141.

[5] Nana Syaodih Sukmadinata, Metode Penelitian Pendidikan. Bandung : PT Remaja Rosdakarya, 2006,pp.72

[6] Ena Widodo, Mukhtar, Konstruksi Kearah Penelitian Dekriptif, Yogyakarta : Avyrouz, 2000, pp.27

[7] Slamet Suyanto, Dasar-dasar Pendidikan Usia Dini, Yogyakarta: Hikayat Publishing, 2005, pp.25

[8] Ace Suryadi, Kerangka Konseptual Mutu Pendidikan dan Pembinaan Kemampuan Profesional Guru. Jakarta: Candimas Metropole, 1993, pp.65-66, pp.70

[9] Ari Handayani, Anak Cerdas Lewat Bermain. Majalah Psikologi Plus, Voleme III, No.10 April 2009. Semarang: PT Niko Sakti, 2009, pp. 07.

[10] Rahmat Suyud, Pokok-pokok Ilmu Jiwa Perkembangan, Yogyakarta: Fakultas Tarbiyah IAIN Sunan Kalijaga Yogyakarta, 1983, pp. 83.

[11] M.J. Langeveld, Ilmu Jiwa Perkembangan, Bandung: Jemmars, 1975, pp. 25. 